\title{
Regional Assembly Supervisory Effectiveness of Supervision in Efforts to Increase The Professionalism of Notary in The Region of Purwokerto and Purbalingga
}

\begin{abstract}
Yuliarti $^{1}$ and Amin Purnawan ${ }^{2}$
Abstract. Supervisory Council is an entity that has the authority to implement the guidance and supervision of a Notary. Regional Supervisory Council (MPD) is formed in the District / City to develop and supervise the notaries who have work areas Regency / City, in accordance with Article 70 UUJN.

The purpose of this study was to analyze the effectiveness of the supervision of the Regional Supervisory Council and the barriers and surveillance solutions Regional Supervisory Council in an effort to increase the professionalism of a notary in Purwokerto and Purbalingga region. This study uses empirical juridical approach, whereas the method of data collection with the literature study and interviews.

Results of research supervision by the MPD in Purwokerto and Purbalingga is still not effective, and can not improve the professionalism of a notary in the region of, because they found many violations of the code of conduct. Obstacles encountered MPD is a shortage of funds, lack of secretarial offices and infrastructure that support the implementation by both the duty and authority MPD limited authority and lack of legal awareness of some of the Notary. Some of the possible solutions is to build its own secretary building with the infrastructure that support the implementation of the duties and authority both MPD and monitoring internal, external, repressive and preventive.
\end{abstract}

Keywords: MPD, Supervision Notary Code of Ethics Violations

\section{Introduction}

The role of the Notary to be very complex and often very different to the applicable provisions as result of rapid social development. Thus it seems difficult to fully define the tasks and jobs Notary. ${ }^{3}$ The task of the notary is set in writing and authentic legal relations between the parties unanimously enlist the services of a Notary. Notary of the main tasks, it can be said Notary have a daunting task of having to provide the public with the best.

Notary institutions play an important role in any development process, because the Notary is a position that runs profession and legal services as well as guarantee and legal certainty for the parties, especially in terms of the smoothness of the development process. Notary as a public official, is one of the organs of the state which is equipped with the legal authority to provide public services, especially in the manufacture of authentic deeds as perfect evidence with regard to actions in the field

\footnotetext{
${ }^{1}$ Student of Master of Notary Law Faculty of Law Unissula Email: yuliarti0612@gmail.com

2 Lecturer in Faculty of Law UNISSULA Semarang

3 Habib Adjie 2003 Tebaran Pemikiran Dalam Dunia Notaris Dan PPAT "Penegakan Etika Profesi Notaris Dari Prespektif Pendekatan Sistem" Lembaga Kajian Notaris dan PPAT Indonesia Surabaya p. 27.
} 
of civil law. ${ }^{4}$

Along with the lack of accountability Notary to the public in performing his duties, he must be guaranteed by the presence of a supervision and guidance by others continuously so that the duties and authority of Notaries are always in accordance with the legal principles that underlie its authority and to avoid the misuse of authority or trust given by government and society.

In carrying out its duties and authorities are supervised by Notary Supervisory Council formed by ministers and the Council of Honor, which is one of the fittings Notary organization, in this case the Indonesian Notary Association (INI). Both institutions are authorized to supervise Notary up with sanctions for Notary who commits a violation of the applicable provisions. There is a difference between these two institutions authority because both of them are formed from different institutions, but they still can not be separated from the presence of the Notary organization.

Supervisory Council is a body that has the authority and obligation to implement the guidance and supervision of a Notary. ${ }^{5}$ Supervisory Council that relate directly to the concerned Notary is MPD also to monitor the actions of a Notary in carrying out its duties and authorities. Supervision of the Notary conducted by the Assembly of Trustees Notary done by involving academic experts, in addition to departmental duties and responsibilities in the field of notaries as well as the Organization of Notaries, the establishment of the Assembly of Trustees notary in each city or county is intended to improve services and legal protection for public service users Public Notary.

Based on the observations which the author, in the district of Purwokerto and Purbalingga many professional code of ethics violations committed by the Notary, but each region had formed the Regional Supervisory Council. It becomes interesting for further study, entitled "Regional Assembly Supervisory Effectiveness Of Supervision In Efforts To Increase The Professionalism Of Notary In The Region Of Purwokerto And Purbalingga ". Based on the background of the above problems, the formulation of the problems in this research are:

- How Effectiveness Monitoring Regional Supervisory Council in Efforts to Enhance Professionalism Notary in the region of Purwokerto and Purbalingga?

- Any obstacles to and solutions Monitoring Regional Supervisory Council in an effort to increase the professionalism of a notary in the region of Purwokerto and Purbalingga?

This research is empirical. The method used is empirical juridical approach. Empirical jurisdiction is a legal research methods that attempt to view the law in terms of real or can be said to see, examine, how the working of the law in society. ${ }^{6}$ Methods of data

\footnotetext{
${ }^{4}$ N.G. Yudara 2006 Notaris dan Permasalahannya (Pokok-Pokok Pemikiran Di Seputar Kedudukan Dan Fungsi Notaris Serta Akta Notaris Menurut Sistem Hukum Indonesia) Makalah disampaikan dalam rangka Kongres INI di Jakarta: Majalah Renvoi Nomor 10.34.III p.72

${ }^{5}$ Article 1 item 6 of Act No. 2 of 2014 on the Amendment of Act No. 30 of 2004 concerning Notary.

${ }^{6}$ Cholid Narbuko dan H. Abu Achmadi 2002 Metodologi Penelitian PT. Bumi Aksara Jakarta p.14
} 
collection in this study using two (2) data collection tool, ie literature study and interviews.

\section{Results and Discussion}

\subsection{Monitoring the effectiveness of the Regional Supervisory Council in Efforts to Improve the Professionalism of Notary in the region of Purwokerto and Purbalingga.}

The purpose of surveillance of the Public Notary is that truly meets the requirements and carry out his duties in accordance with the provisions of the legislation in force and a code of conduct for security Notary of the general public. The purpose of the code of conduct made, in this case the code of ethics Notary, in essence, is to maintain the honor and nobility of Notary office. A Notary should live and behave well in carrying out his post on the basis of values, morals and ethics Notary. Based on the values, morals and ethics Notary, the Notary office nature pengembanan profession is service to the public (client) independently and impartially. ${ }^{7}$

Guidance and supervision institutions (Supervisory Council) of the Notary formed by the Ministry of Justice needs to be streamlined and improved quality and quality, because it is expected to run a professional Notary office by constantly improving the quality of professionalism and legal protection to the public. The role of the Supervisory Council is crucial in fostering and overseeing the ongoing Notary office of behavior in conducting their personal self and outside of his office as a spearhead to ensure legal certainty to people who use services Notary. The purpose of surveillance so that the Notary when executing the task and the Notary office, in order to safeguard the public interest, because the Notary appointed by the government. ${ }^{8}$

Article 70 UUJN, has determined the authority of the Regional Supervisory Council of Notaries as follows: ${ }^{9}$

- held a hearing to examine the alleged violation or breach Notary Code implementing the Notary office.

- conduct an examination of the Notary Protocols regularly 1 (one) time in 1 (one) year or any time it deems necessary.

- give permission for the leave of absence of up to six (6) months.

- Substitute Notary set by considering the proposal concerned Notary.

- Notary Protocols determine the storage area at the time of the handover protocol notary are aged 25 (twenty five) years or more.

- appoint notaries who will act as a temporary holder of the Notary Protocol which was adopted as state officials.

\footnotetext{
${ }^{7}$ Interview with Ratnawaty Notary in Purbalingga 6 September 2018

${ }^{8}$ G.H.S. Lumban Tobing 1999 Peraturan Jabatan Notaris Cet. 5 Airlangga Jakarta p. 301.

${ }^{9}$ Act No. 30 of 2004
} 
- receive reports from the public regarding the alleged violation or breach Notary Code provisions in the Law on Notary.

- create and submit a report To the Supervisory Council of the Territory.

Effectiveness of supervision is an important thing to be done by the MPD. MPD has an important role for Notary-Notary shaded area because MPD has the scope of authority held a hearing to examine the alleged violation of Notary Code, breach of execution office Notary, and the behavior of the Notary outside performing his respective duties as Notary to interfere with or influence Notary office task execution.

Professionalism means in working Notary Notaries must comply with the Procedural Operational standards (SOP) of starting work, run and produce accurate results. To enhance professionalism in working Notary, the Notary also be subject to a code of ethics Notary. The elements of professional behavior is as follows:

- Having professional behavior

- Opt in national development in the field of law

- Uphold the honor and dignity

- Expertise backed by knowledge and high experience

- Moral integrity means to avoid anything that is not good despite their remuneration high, the implementation of professional tasks are aligned with societal values, manners, and religion

- Honestly not only on the second or the third party, but also to himself

- Not solely considerations of money, run devotion, does not distinguish between those capable and incapable.

- Sticking to a code of ethics as therein defined traits that must be owned by the Notary, including a perfect Indonesian language. ${ }^{10}$

In carrying out his duties and to the interests of the general public, a notary shall be under the supervision of a neutral and independent agency or independent. Supervision over the implementation of the code of conduct carried out in the following manner:

- On the first level is done by the regional board Indonesian Notary Association and the Honorary Board of the Region;

- On appeal carried by the county board Indonesian Notary Association and the Council of Honor Territory;

- At the end of the level is done by the central committee of the Indonesian Notary Association and the Honorary Board of the Center.

Assembly Regional Supervisor (MPD) are processing violations of the Code there are reports from the public and the Notary itself and act when it has happened and the nature of the investigation depends on the number of reports received since Purbalingga itself Honor Council has not been established and the problems of

${ }^{10}$ Interview with Sri Ningrum Notary in Purwokerto 6 September 2018 
violations of the Code does not becomes a severe problem, the extent of the negligence and carelessness Notary. ${ }^{11}$

Judging from the authority Chairman of Council of Regional Supervisor (MPD) Notary has the authority to review the performance of the Assembly Regional Supervisor (MPD) conduct periodic checks of 1 (one) year in case of violations of the code of conduct will be posted on the Investigation Report was sent to the Assembly of Trustees Region (MPW) because he knew of the investigation, reports from the public, to gather facts that actually occurred and evidence of a violation and the Regional Supervisory Council (MPD) conducts proceedings by forming a team of inspectors. The results are sent to the Regional Supervisory Council (MPW), and conduct trials back and sanction authority of the Supervisory Council of Territory (MPW) instead of the Supervisory Council of Regions (MPD). ${ }^{12}$

The code of ethics violations occur and known by the Regional Supervisory Council of the Association of Regional Notary Indonesia in Purwokerto District, among others:

- Reports related to the alleged public on neutral nature, which sided with one party client

- Installation nameplate Notary not done according to the rules, such as the size is not appropriate, the provision of accessories on the nameplate such as decorative lighting, and color in addition to black and white

- The presence of the maintenance of the deed unfinished and left to let the protracted

- Leave a blank form to be signed by the client that the contents of the deed of the client does not know. ${ }^{13}$

The code of ethics violations occur and known by the Regional Supervisory Council of the Association of Regional Notary Indonesia in Purbalingga include: ${ }^{14}$

- Deed is very long

- Notary more use of time outside the office

- Restraining client file in order not to move the Notary.

- Notary falsifying data in deed

Notary code violations is a reality that many occur and can not be denied in practice. This is due to the intense competition in practice notaries who originated from the growing number of Notaries. This condition will get worse and a dilemma because of the weak dissemination of the code of conduct and is not optimal supervision carried out by the Notary professional organizations, in this case the Indonesian Notaries Association. In addition to the self-contained among the Notary's behavior and perception is shrugging off the code of conduct Notary. ${ }^{15}$

\footnotetext{
${ }^{11}$ Interview with the Chairman of MPD Purbalingga Tajudin Nasution 6 September 2018

12 Interview Faiz Member of the MPD Purwakerto 6 September 2018

13 Ibid.

14 Ibid.

15 Interview with Sri Ningrum Notary in Purwokerto 6 September 2018
} 
With still many code violations in the region Purwokerto and Purbalingga then according the author supervision by the MPD has not been effective, and not been able to improve the professionalism of a notary in the region. Urgency sanction code of conduct is essential in order to realize the professionalism of notary because the effective regulatory framework necessary sanctions, because sanctions will give effect and deterrent force against those who commit violations.

\subsection{Obstacles and solutions Monitoring Regional Supervisory Council in an effort to increase the professionalism of a notary in the region of Purwokerto and Purbalingga}

MPD obstacles in conducting surveillance Notary in Purwokerto and Purbalingga are as follows:

- Funds used Notary Regional Supervisory Council Purbalingga is very limited for the guidance and supervision. ${ }^{16}$

- The absence of the office secretarial and also the lack of completeness of facilities and infrastructure that support the implementation by both the duties and authority of the Assembly Regional Supervising Notary in the region of Purwokerto and Purbalingga, because at this time the office MPD Notary still riding with the Regional Office Ministry of Law and Human Rights in Banyumas. ${ }^{17}$

- Regional Supervisory Council has only limited authority to inspect code violations committed by the Notary.

- Lack of community participation in reporting alleged violations of Notaries

- Lack of awareness of the law of some Notary Purwokerto and Purbalingga

- MPD does not have the authority to impose sanctions on violating Notary Act

The solution can be conducted by MPD MPD Purwokerto and Purbalingga to realize effective supervision so that the professionalism of Notaries can be improved is by doing some of the following solutions:

- Purwokerto and Purbalingga MPD MPD must have its own secretariat office and have an adequate supporting infrastructure.

- Chairman of the MPD should be more assertive to its members in carrying out the task.

- Implement Internal supervision, ie supervision carried out by a body that the organizational / structural still included within the government itself. Monitoring carried out by the leader / supervisor directly, either at central level carried out by the Central Supervisory Council (MPP) of Notary.

- To supervise external ie Monitoring carried out by the organs / institutions organizational / structural outside of government (executive), for example in the supervision conducted by the Organization for Notary namely THIS area

16 Op.Cit Interview Tajudin Nasution...

${ }^{17}$ Interview Results Faiz Member of the MPD Purwakerto 6 September 2018 
Purwokerto and Purbalingga to the Notary in Purwokerto and Purbalingga through the Honorary Board of the Regional.

- Preventive and repressive supervision Referred Preventive supervision is supervision carried out before issued a decision / provision, so that corrective and recover an erroneous action, also called a posteriori supervision. Preventive surveillance associated with the monitoring of the Notary, among other things stipulated in Article 70 Letter b, c, d, e, f and h UUJN, Article 13 paragraph (2) d UUJN, which regulates the action taken against dugaan- alleged violations committed by the Notary to UUJN and Code of Conduct.

\section{Closing}

\subsection{Conclusion}

From the description above, the conclusions of this research are:

- Supervision by the MPD in Purwokerto and Purbalingga is still not effective, and have not been able to improve the professionalism of a notary in the region of, because they found many violations of the code of conduct in the region of Purwokerto and Purbalingga, then according to the authors of Urgency sanction code of conduct is essential in order to realize the professionalism of the Notary for within the framework of the necessary regulatory ineffectiveness of sanctions, because sanctions will give effect and deterrent force against those who commit violations.

- Barriers that MPD Purbalingga and Purwokerta include limited budget funds to carry out supervision and oversight, the lack of office secretarial and lack of completeness of facilities and infrastructure for today's office MPD is still riding at the local Ministry of Justice and Human Rights in Banyumas, MPD has only limited authority in checking the Notary who violates the code of conduct, lack of community participation in reporting alleged violations of Notaries, the lack of legal awareness of some Notary Purbalingga MPD does not have the authority to impose sanctions on violating Notary Act

- Solutions that can be done is well MPD Purbalingga and MPD Purwokerto must have an office secretariat itself accompanied with supporting facilities and infrastructure are adequate, Chairman of the MPD should be more assertive to its members in implementing the work program, doing supervision Intern, and supervision of external, as well as supervise the Preventive and repressive

\subsection{Suggestion}

- Notary hoped that a better understanding of the code of ethics, and expand knowledge of the authentic act and its manufacture are set in UUJN.

- Notary must have a moral personality and a powerful idealistic, should be aware that the demands of professional ethics is a serious obligation. 
- Should the Supervisory Council which oversees the Notary in performing their duties and positions are supervisors who have the knowledge and understanding of the notaries in particular in the manufacture of an authentic deed and have high integrity.

- This organization committee is expected to be more intensive in meetings involving elements of the MPD to discuss the issues surrounding the implementation of the Notary office, especially with regard to the code of ethics and the law, so that the Notary better understand and know about his duties with regard to the Code and the enactment Act.

\section{Bibliography}

[1] Cholid Narbuko dan H. Abu Achmadi, 2002, Metodologi Penelitian, PT. Bumi Aksara, Jakarta, p.14

[2] G.H.S. Lumban Tobing, 1999, Peraturan Jabatan Notaris, Cet. 5, Airlangga, Jakarta, p. 301.

[3] Habib Adjie, 2003, Tebaran Pemikiran Dalam Dunia Notaris Dan PPAT "Penegakan Etika Profesi Notaris Dari Prespektif Pendekatan Sistem", Lembaga Kajian Notaris dan PPAT Indonesia, Surabaya, p. 27.

[4] N.G. Yudara, 2006, Notaris dan Permasalahannya (Pokok-Pokok Pemikiran Di Seputar Kedudukan Dan Fungsi Notaris Serta Akta Notaris Menurut Sistem Hukum Indonesia), Makalah disampaikan dalam rangka Kongres INI di Jakarta: Majalah Renvoi Nomor 10.34.III, p.72

[5] Interview Faiz, Member of the MPD Purwakerto, 6 September 2018

[6] Interview with Ratnawaty, Notary in Purbalingga, 6 September 2018

[7] Interview with Sri Ningrum, Notary in Purwokerto, 6 September 2018

[8] Interview with the Chairman of MPD Purbalingga, Tajudin Nasution, 6 September 2018

[9] Act No. 30 of 2004

[10]Act No. 2 of 2014 on the Amendment of Act No. 30 of 2004 concerning Notary. 